просвещения. - 1924. - № 30. - С. 30-31. 12. Сидорчук Н. Г. Організація самоосвітньої діяльності майбутніх учителів: теорія та технологія формування: [монографія] / Нінель Сидорчук . - Житомир : Вид-во ЖДУ, 2004.- 168 с. 13. Сухомлинська О. В. Історико-педагогічний процес: нові підходи до загальних проблем / О. В. Сухомлинська. - К. : АПН, 2003. - 68 с. 14. Третье Всеукраинское совещание по просвещению (15-27 июня 1921 г.): Выдержки из материалов работы пленума и секций: Резолюции. - Харьков, 1922. - 207 с. 15. ЦДАВОВ України, ф. 166, оп. 2, спр. 563, 1921 р., 19 арк. 16. ЦДАВОВ України, ф. 166, оп. 2, спр. 281, 1921 р., 134 арк. 17. ЦДАВОВ України, ф. 166, оп. 1, спр. 416, 1919 р., 34 арк. 18. ЦДАВОВ України, ф. 166, оп. 2, спр. 254, 1922 р., 179 арк. 19. ЦДАВОВ України, ф. 166, оп. 2, спр. 1227, 1922/23 н. р., 133 арк. 20. Чанбарисов Ш. Х. Формирование советской университетской системы / Ш. Х. Чанбарисов. - М. : Высшая школа. - 1988. -255 с.

\title{
ПОНЯТТЯ ШКІЛЬНОЇ ДИСЦИПЛІНИ В ПЕДАГОГІЧНОМУ СПАДКУ П. КАПТЕРЕВА
}

Герасименко Л. В. Поняття шкільної дисципліни в педагогічному спадку П. Каптерева.

У статті проаналізовано погляди видатного педагога другої половини XIX-початку XX століття П. Каптерева щодо ролі дисципліни в педагогічному процесі школи. Розглянуто виховний потенціал дисципліни, способи ії організації та управління нею.

Ключові слова: педагогічний процес, дисципліна, внутрішня дисципліна, дисциплінованість.

Герасименко Л. В. Понятие школьной дисциплины в педагогическом наследии П. Каптерева.

В статье проанализированы взгляды выдающегося педагога второй половины XIX - начала XX века П. Каптерева относительно роли дисциплины в педагогическом процессе школы. Рассмотрен воспитательный потенциал дисциплины, способы ее организации и управления.

Ключевые слова: педагогический процесс, дисциплина, внутренняя дисциплина, дисциплинированность.

Gerasymenko L. V. The concept of school discipline in the pedagogical legacy of P. Kaptieriev.

The article analyzes the views outstanding teacher of the second half of the nineteenth-early twentieth century P. Kapteryeva on the role of discipline in the pedagogical process of the school. Considered educational potential discipline, how the implementation and regulation.

Key words: pedagogical process, discipline, domestic discipline, discipline.

Сучасні процеси реформування в освіті, спрямовані на гуманізацію та демократизацію, внесли суттєві зміни в організацію шкільного педагогічного процесу i в систему взаємовідносин між учителями й учнями. Така ситуація вимагає впровадження дисципліни, яка б сприяла формуванню в учнів гуманістичних цінностей та індивідуальної свободи, понять про права людини та громадянську відповідальність. Праці сучасних педагогів Л. Адріанової, В. Гмурмана та М. Левітова, присвячені дослідженню ролі дисципліни в середній загальноосвітній школі; О. Горчакової, яка розглядала дисципліну у контексті гуманістичних поглядів М. Пирогова; історичні роботи 3. Палюх, С. Самаріної про дисципліну в історії шкільної освіти України другої половини XIX - початку XX століття становлять цікавий матеріал, наштовхують на подальші роздуми, підводять до висновку про складність i невичерпність проблеми дисципліни. Бажання сприяти ії грунтовному розробленню спонукало до вивчення поглядів видатного вітчизняного педагога другої половини XIX - початку XX століття П. Каптерева, який розкрив виховний потенціал дисципліни та запропонував оригінальні методи їі регулювання.

Meта статmi - проаналізувати погляди П. Каптерева на дисципліну як засіб виховання в педагогічному процесі загальноосвітньої школи, методи її впровадження та регулювання.

Педагогічний процес у дидактиці П. Каптерева системо утворювальне поняття, що дозволяє грунтовно й багатогранно представити взаємопов'язану діяльність учителя й учнів, спрямовану на сприяння саморозвитку останніх, їх вдосконаленню відповідно до визначеного ідеалу і з урахуванням індивідуальних особливостей. Навчально-виховний процес об'єднує в спільній діяльності багатьох людей, вимагає використання різних форм організації навчання, 
залучення учнів до активної діяльності, що потребує певного порядку, узгодження дій дисципліни. П. Каптерев розглядав цей невід'ємний складник організації навчально-виховної діяльності як умову успішного навчання і дієвий засіб виховання, де гармонійно поєднувалися діяльність вчителя й учнів: «Привести в гармонію інтереси окремих учнів, учителя й всього шкільного товариства і тим самим створити основу для дружної спільної роботи всіх - ось у чому полягає призначення дисципліни» [2, с. 611].

Висвітлюючи питання організації порядку в шкільному житті, П. Каптерев спирався на думку П. Юркевича, який уважав дисципліну основним способом розвитку волі дітей на основі підпорядкування не бажанням вихователя, а загальній волі і загальному розуму, що втілені в правилах, які визнаються однаково і вчителем, і учнями. Слід зазначити, що П. Юркевич у «Курсі загальної педагогіки з додатками» (1869) визначив закони обсягу й складності дисциплінарних заходів, основні положення яких перегукувалися 3 розумінням шкільного порядку П. Каптеревим. Так, як і П. Юркевич, П. Каптерев уважав, що дисципліна має виходити 3 внутрішніх потреб учасників педагогічного процесу, в іншому випадку іiі дотримання може регулюватися тільки силовими методами. Обидва педагоги були переконані, що, чим більше моральних, шляхетних особистостей серед вихованців, тим менше має бути дисциплінарних обмежень. Науковці І. Каптерев, П. Юркевич мали одностайну думку в тому, що пов'язували обсяги дисциплінарних правил із віком дітей, рівнем розвитку шкільної громади та природністю умов навчання. Отже, обидва педагоги обстоюють положення, що, чим менші діти, тим конкретніше мають формулюватися правила поведінки, чим розвиненіша шкільна, класна громада, тим менше потрібно правил для регулювання іiі діяльності; умови навчання, які не відповідають природі дитини, потребують більше дріб'язкових правил для регулювання діяльності дітей $[2,8]$. Тому П. Каптерев наголошував на тому, що дисципліна не могла бути єдиною для всієї школи, вона мала різнитися залежно від віку і навіть конкретного класу. Ця оригінальна позиція педагога-гуманіста абсолютно розходилася 3 практикою організації навчання у тогочасній школі, основою дисципліни в якій було абсолютне підпорядкування уставу навчального закладу.

Заслуга П. Каптерева полягала в тому, що, на відміну від тогочасної традиції, він упроваджував демократичні ідеї в організацію шкільного навчання, спрямовані на забезпечення свободи особистості в навчально-виховній діяльності для її самовдосконалення та вільного виявлення власних інтересів і можливостей.

Так, П. Каптерев не погоджувався з П. Юркевичем щодо «дисциплінарного виховання» дітей із народу, які не мали ні часу, ні засобів для глибокої інтелектуальної й моральної освіти. П. Каптерев наполягав на створенні однакових умов навчання і виховання для різних верств населення.

К. Єльницький був близький до розуміння дисципліни П. Каптеревим. У його працях зазначалося, що встановлення й підтримання порядку в школі необхідне для успішності навчання, оскільки сприяє регуляції й узгодженню спільної діяльності учнів та вчителя на уроці. Зовнішній порядок ставився К. Сльницьким вище за методичні прийоми: «За відсутності порядку - й методично правильне опрацювання матеріалу не завжди досягає оптимального результату» [1, с. 130]. Але П. Каптерев відкидав аргументацію К. Сльницького щодо необхідності постійних зовнішніх вимог керування для незміцнілого дитячого розуму. Аналіз праць П. Каптерева «Дидактичні нариси» $(1885,1915)$, «Педагогічна психологія» (1914) надає змогу зауважити, що основну задачу дисципліни він убачав не у вихованні послуху в дітей, а в розвитку їхньої здатності до самокерування й розумного мотивування своїх дій. Самі учні мали усвідомити іï необхідність, оскільки в підпорядкуванні ій проступали власні розум та воля. Вперше в педагогічній науці П. Каптерев наголосив на тому, що педагогічна дисципліна повинна спрямовуватися не на пригнічення енергії учнів, а на іiі спонукання щодо самовдосконалення, наполегливості й витримки. Отже, найвища мета дисципліни - розвиток зовнішнього і внутрішнього самоврядування тих, хто навчається: «Дисципліна не може бути кимось привнесеною, вона тільки може бути виробленою всім шкільним товариством, тобто вчителем й учнями; інакше вона буде незрозумілою учням, нав'язаною, абсолютно не цінною для них i морально необов'язковою» [2, с. 612]. Тому П. Каптерев протестував проти абсолютного підпорядкування волі старших, що, на його думку, знижувало рівень свідомості, самоконтролю, відповідальності за свої вчинки, а значить не мало виховного впливу: «Ідеал педагогічної дисципліни не розслаблена, скорена під владою і забита людина, а сильна, мужня 
й вільна, але при цьому повністю відповідальна за свої дії та вчинки» [2, с. 614]. Основою навчально-виховної діяльності, з позиції демократичних переконань П. Каптерева, мали стати ініціативність і самодіяльність. Науковець був переконаний, що свобода, яка надається учням у процесі проведення навчальних занять і дозвілля, спонукає до виховання таких рис в учнів, як діловитість, стійкість, взаємоповага та відповідальність: «Повага до особистості учня, визнання iii свободи й самостійності повинно пройняти весь шкільний порядок, при чому, звичайно, впроваджуються й основи відповідальності учнів за всі їхні дії» [2, с. 249]. Це, на думку науковця, впливало на формування самодисципліни й загалом характеру особистості школяра.

Зовсім інакше тлумачили необхідність виховного впливу дисципліни сучасники П. Каптерева С. Миропольський та К. Сльницький. Так, С. Миропольський уважав, що велике виховне значення в педагогічному процесі мало обмеження дисциплінарними заходами слабкої волі дітей: «Дисципліна обмежує не чисті, не добрі наміри дитячої волі, але ії відхилення, погані нахили, негативний вплив яких зазнає дитина» [5, с. 65]. Утримання, послух, на думку педагога, зумовлювало перемогу вищих потреб над нижчими, «владу духу над чуттєвим егоїзмом». Подібні думки висловлював у «Курсі дидактики» (1909) і К. Сльницький, зазначаючи, що оптимальний, методично доцільний порядок має виховне значення, стримуючи учнів, які 3 часом, виконуючи зовнішні вимоги і підтримуючи зовнішній порядок, навчаються керувати своїми вчинками, усвідомлювати необхідність підпорядкування законним вимогам, а також виконувати свої обов'язки. Тобто науковець підкреслював особливу роль дисципліни не тільки в упорядкуванні зовнішньої поведінки, але й у формуванні шляхетності душі [1]. На відміну від С. Миропольського і К. Єльницького, П. Каптерева цікавив не стільки вплив зовнішнього порядку на поведінку учнів, скільки процес формування дисциплінованості як риси характеру школяра. Науковець наголошував, що значно важливіше не кількість записів за проступки, а те, що відбувалося в душі учня після здійснення вчинку, чи працює він над власним удосконаленням: «Якщо залишаються невідомими внутрішні мотиви дій, ті процеси, які зумовлюють ті чи інші вчинки, то останні з педагогічної точки зору нецінні» [2, с. 225]. Значним унеском у педагогічну науку другої половини XIX століття було питання внутрішньої мотивації поведінки вихованців, яке в «Дидактичних нарисах» $(1885,1915)$ підняв П. Каптерев. Так, на його думку, тільки тоді вчинки мають моральну педагогічну цінність, коли виражають відповідні внутрішні процеси, коли вони свідомо мотивовані. Тому оцінка зовнішньої поведінки без виявлення внутрішніх спонук не здійснює виховного впливу і не сприяє саморозвитку учнів.

Заслуговує на увагу, що ідеї П. Каптерева знаходили впровадження в шкільну практику. Вивчення архівних матеріалів надало змогу виявити, що вчителі Уманської прогімназії звертали увагу не тільки на необхідність зовнішнього порядку, а й на внутрішню дисципліну (усвідомлення учнями необхідності підпорядковуватися спільним правилам, які регулюють діяльність), що зазначено в протоколі засідання педагогічної ради від 09.01.1891 року [10]. Ідея П. Каптерева щодо важливості формування внутрішньої дисципліни підтримувалася i педагогічним колективом Черкаської чоловічої прогімназії. Основним методом її формування вчителі вважали переконання: «... і діючи на учнів переважно через переконання і роз'яснення їм шкідливих наслідків проступків, лінощів і неуспішності...» [10, арк. 129].

Однак, розуміючи особливості дитячої природи, слабкість волі й характеру, П. Каптерев вивчав питання методів регулювання дисципліни. На основі аналізу історії педагогіки науковцем було визначено три найпоширеніших дисциплінарних прийоми: тілесні покарання, похвала й осудження, система природних покарань. Тілесні покарання П. Каптерев уважав неможливим використовувати в процесі виховання: «Побиття - надзвичайно грубий прийом, особливо щодо дітей, це засіб виховання скотів, а не людей» [2, с. 616]. У своїх висновках П. Каптерев грунтувався на працях своїх видатних попередників-гуманістів М. Пирогова, К. Ушинського та П. Юркевича. Так, у статті «Чи потрібно сікти дітей і сікти в присутності інших» (1859) М. Пирогов одним із перших наголосив, що побиття породжує брехню, негативні почуття і шкодить здоров'ю вихованців. Цю ж думку повністю поділяли К. Ушинський та П. Юркевич, які визнавали основним способом коригування поведінки учнів - усвідомлення ними неправильних вчинків і їх причин. Цієї ж думки дотримувався й П. Каптерев, наголошуючи, що тілесні покарання можуть примусити до будь-чого, але переконати людину - не в змозі. Думку П. Каптерева щодо заборони тілесних методів покарання поділяли сучасники науковця К. Єльницький, П. Лесгафт та К. Яновський, які теж 
гостро виступали проти тілесних дисциплінарних заходів. Так, П. Лесгафт у статті «Значення школи» (1907) наголошував: «Тільки людина може виховати людину, а звір - звіра» [4, с. 348]. К. Яновський уважав, що будь-які покарання, не обов'язково тілесні «..повинні використовуватися в рідких і навіть крайніх випадках» і мають обов'язково узгоджуватися 3 іншими дисциплінарними заходами. Покарання ж у грубій формі (гострих висловлювань, сарказму, лайки), що принижують гідність учня, уважав недопустимими [9].

Варто зазначити, що на початку XX століття гуманістичні ідеї щодо організації шкільного навчання виголошувалися і в урядових документах. Так, у циркулярі Міністерства народної освіти щодо підвищення дисципліни в навчальних закладах від 28.06.1903 за підписом М. Зенгера було викладено думку, подібну до підходу П. Каптерева. У документі наголошено, що «виключно караючими заходами падіння дисципліни не може бути зупинено, в цьому, звичайно, немає сумнівів» [11, арк. 79 зв.]. Міністру були близькі погляди гуманістівсучасників, зокрема П. Каптерева, про заборону тілесних покарань учнів і необхідність спонукання їх до усвідомленості власної неправоти та її наслідків для оточення.

П. Каптерев, аналізуючи інші дисциплінарні методи - похвалу й осудження, теж уважав їх непедагогічними, оскільки вони спонукали егоїстичні мотиви і не впливали на формування моральності: «Похвала за доброчинність - засіб виховати егоїста, а не справді добропорядну людину» $[2$, с. 618]. А осуд, особливо публічний, на думку науковця, завдавав не менше страждань, ніж тілесне покарання, оскільки вражав душу учня.

Здійснивши глибокий педагогічний аналіз методу «природних наслідків», пропонованих Ж.-Ж. Руссо, Г. Спенсером, П. Каптерев дійшов висновку про його недосконалість (не завжди наслідок збігався з тяжкістю проступку; наслідки могли завдати шкоди життю й здоров'ю дітей; педагоги позбавлялися дієвого впливу на особистість учнів, маючи можливість тільки попереджати їх про негативні наслідки тісї чи іншої поведінки).

Отже, жоден із розроблених і використовуваних в історії педагогіки методів регулювання дисципліни не задовольняв П. Каптерева. Пропонуючи свій оригінальний метод, науковець виходив 3 мети педагогічного процесу і констатації виховного потенціалу шкільного товариства, члени якого об'єднані спільною діяльністю й інтересами. За таких умов, на думку науковця, легше було розробити спільні правила, що свідомо визнавалися і регулювалися всіма членами шкільного колективу. П. Каптерев уважав доцільним обговорення проступку учнями класу, які мали право тимчасово відлучити того, хто порушив дисципліну, від спільноти товаришів: «Інших покарань не повинно бути, тому що для них немає достатньо твердого педагогічного підгрунтя» [2, с. 620]. При цьому науковець підкреслював, що усунення від колективу не означало знеславлення порушника дисципліни, це не було осудом його діянь, а «...тільки визнання неузгодження певного вчинку 3 шкільним порядком» [2, с. 620]. П. Каптерев переконливо доводив, що тільки колектив мав найбільший вплив на особистість і здатен упроваджувати ті чи ті дисциплінарні обмеження. Такий підхід до дисциплінарних покарань свідчив про абсолютну свободу вибору власної поведінки кожним членом колективу, відсутність будь-якого тиску на особистість.

3 таким підходом до виховання дисциплінованості не погоджувався видатний гуманіст XX століття В. Сухомлинський. Він підкреслював: «Я глибоко переконаний, що деякі прийоми використання колективу як способу глибокого впливу на дитину - лише ознака безсилля, розгубленості педагога, нерозуміння самої сутності колективного виховання» [7, с. 375]. На думку науковця, дисциплінованість мала виховуватися вірою в учня, його кращі якості, повагою до нього. Виховна ж сила колективу, на думку В. Сухомлинського, полягала не у викритті проступків членів колективу, а в піднесенні духу дитини. За переконанням педагога, чим менше колектив займається розбором різноманітних конфліктних ситуацій, тим більшу виховну силу він має.

Отже, П. Каптерев на основі грунтовного аналізу педагогічних праць своїх попередників та сучасників, а також узагальнюючи й систематизуючи власний досвід, розкрив сутність виховного потенціалу дисципліни, вперше поставивши питання формування внутрішньої мотивації поведінки школярів як основи виховання дисциплінованості. Заслуга П. Каптерева полягала в розробленні оригінального підходу до виховання дисциплінованості, який не потребував ломки особистості, але спонукав до самоаналізу, самоконтролю, витримки, самостримання на основі усвідомлення своєї приналежності до загального шкільного порядку і його необхідності. 


\section{Література}

1. Ельницкий К. Курс дидактики: [пособие для учебных заведений, в которых преподается педагогика] / Кирилл Ельницкий - СПб. : Изд. М. М. Гутзаца, 1909. - 173 с. 2. Каптерев П. Ф. Избранные педагогические сочинения / Петр Федорович Каптерев; под ред. А. М. Арсеньева. - М. : Педагогика, 1982. - 704 с. 3. Каптерев П. Ф. О школьном самоуправлении и школьной дисциплине / П. Ф. Каптерев // Педагогическая мысль. - 1921. - № 1. - 4. - С. 19-31. 4. Лесгафт П. Ф. Избранные педагогические сочинения / Петр Францевич Лесгафт. - М. : Педагогика, 1988. - 400 с. 5. Миропольский С. И. Дидактические очерки. Ученик и воспитывающее обучение в народной школе / Сергей Иеренеевич Миропольский. - СПб: Типография И. Н. Скороходова, 1890. - 78 с. 6. Пирогов Н. И. Избранные педагогические сочинения / Николай Иванович Пирогов; сост. А. Н. Алексюк, Г. Г. Савенок. - М. : Педагогика, 1985. - 496 с. 7. Сухомлинский В. А. Избранные произведения в 5 томах / Василий Александрович Сухомлинский. - К. : Рад. школа, 1980. - Т. 5. - 680 с. 8. Юркевич П. Д. Курс общей педагогики с приложениями / Памфил Даниилович Юркевич. - М., 1869. - 404 с. 9. Яновский К. П. Мысли о воспитании и обучении / Кирилл Петрович Яновский. - СПб. : Тип. И. Н.Скороходова, 1900. - 299 с. 10. Центральний державний історичний архів м. Київ. Ф 707 Управление попечителя Киевского учебного округа Оп. 143. Спр. 60 «Копии протоколов заседаний педагогического совета прогимназий за 1 полугодие 1891 года». - 1891. - 458 арк. 11. Центральний державний історичний архів м. Київ. Ф 707 Управление попечителя Киевского учебного округа. Оп. 317. Спр. 503 «Протоколы заседаний за 1903 год». - 1903. - 113 арк.

Наталія Зайцева

\section{ОСОБЛИВОСТІ ЗМІСТУ ДВОМОВНОГО НАВЧАННЯ В СЕРЕДНІХ ШКОЛАХ США}

Зайцева Н. Г. Особливості змісту двомовного навчання в середніх школах США.

У статті розглянуто особливості змісту двомовного навчання в середній освіті США. На основі аналізу змісту двомовного навчання в середніх школах Сполучених Штатів Америки виокремлено найважливіші його складники, розкрито специфіку полікультурного розвитку учнів в навчальних закладах США.

Ключові слова: двомовне навчання, зміст двомовного навчання, багатомовний розвиток, полікультурний розвиток, акультурація.

Зайцева Н. Г. Особенности содержания двуязычного обучения в средних школах США.

В статье рассмотрены особенности содержания двуязычного обучения в среднем образовании США. На основе анализа содержания двуязычного обучения в средних школах Соединенных Штатов Америки выделены самые важные его составляющие, раскрыта специфика поликультурного развития в учебных заведениях США.

Ключевые слова: двуязычное обучение, содержание двуязычного обучения, многоязычное развитие, поликультурное развитие, аккультурация.

Zaitseva N. G. The features of the content of bilingual education in secondary schools of the USA.

The article deals with the review of the content of secondary bilingual education in the USA. On the basis of the analysis of the content of bilingual education in the USA secondary schools its most important components and the specifics of pupils' polycultural development were identified.

Key words: bilingual education, content of bilingual education, multilingual development, multicultural development, acculturation.

Розвиток полікультурності і багатомовності в контексті світових трансформацій зумовлює поширення двомовного навчання як засобу надання загальної і подальшої освіти учням, які мають різну національну приналежність. Сполучені Штати Америки вважають однією 3 найбільш багатомовних країн світу. Недарма цю країну порівнюють із «салатним блюдом», де представлено багато націй (щонайменше 322) [3]. Потреба надання якісної освіти учням будьякої етнічної приналежності спричинила необхідність запровадження двомовного навчання в освітніх закладах країни. Спираючись на визначення вітчизняних та зарубіжних науковців, феномен двомовного навчання в умовах американської школи ми можемо трактувати як цілеспрямований процес формування у школярів двомовності, або здатності послуговуватися в 